\title{
KEMAMPUAN PEMECAHAN MASALAH SISWA KELAS V PADA MATERI GEOMETRI DITINJAU DARI GAYA KOGNITIF
}

\author{
Vivi Dwi Ramadhani ${ }^{1}$ \\ Goenawan Roebyanto ${ }^{2}$ \\ Siti Umayaroh ${ }^{3}$ \\ 1,2,3 Pendidikan Guru Sekolah Dasar, Universitas Negeri Malang, ramadhanivividwi@gmail.com
}

\begin{abstract}
Learning mathematics can develop students' thinking patterns in solving problems. The purpose of this study is to describe the ability to solve geometry problems based on independent and field dependent cognitive styles in fifth grade students of SD Karangbesuki 2 Malang. The research subjects consisted of 2 students with independent field cognitive styles and 2 students with field dependent cognitive styles. Based on the results of the study, students who have independent field cognitive style in this study are able to solve geometry problems based on Polya's steps, namely (1) able to find aspects that are known and asked, (2) able to draw up problem solving strategy relevant to what was asked, (3) able to solve the problem correctly, and (4) able to draw conclusions from the answers. Whereas students who have a field dependent cognitive style experience difficulties, namely (1) not including complete information, (2) being less able to prepare a completion plan, (3) the results of the answers are less precise, (4) not doing a look back step.
\end{abstract}

Keywords: geometry problem solving, polya steps, cognitive style, field independent, field dependent

\begin{abstract}
Abstrak: Pembelajaran matematika dapat mengembangkan pola berpikir siswa dalam memecahkan masalah. Tujuan penelitian ini untuk mendeskripsikan kemampuan pemecahan masalah geometri berdasarkan gaya kognitif field independent dan field dependent pada siswa kelas V SDN Karangbesuki 2 Kota Malang. Subjek penelitian terdiri dari 2 siswa dengan gaya kognitif field independent dan 2 siswa dengan gaya kognitif field dependent. Berdasarkan hasil penelitian diketahui bahwa siswa yang memiliki gaya kognitif field independent pada penelitian ini mampu melakukan pemecahan masalah geometri berdasarkan langkah-langkah Polya, yaitu (1) mampu menemukan aspek yang diketahui dan ditanyakan, (2) mampu menyusun rencana yang relevan dengan yang ditanyakan, (3) mampu menyelesaiakan masalah dengan benar, dan (4) mampu membuat kesimpulan dari jawabannya. Sedangkan pada siswa yang memiliki gaya kognitif field dependent mengalami kesulitan, yaitu (1) belum mencantumkan informasi yang lengkap, (2) kurang mampu dalam menyusun rencana penyelesaian, (3) hasil akhir jawaban kurang tepat, (4) tidak melakukan pemeriksaan kembali.
\end{abstract}

Kata kunci: pemecahan masalah geometri, langkah-langkah polya, gaya kognitif, field independent, field dependent. 
Matematika berperan penting dalam kehidupan manusia, terutama pada perkembangan ilmu pengetahuan saat ini. Matematika menjadi salah satu muatan yang diajarkan di Sekolah Dasar (SD). Menurut Daryanto \& Raharjo (2012) materi matematika yang diajarkan di sekolah dapat menjadi bekal bagi siswa melalui beberapa kompetensi, yaitu mampu berpikir logis, analitis, sistematis, kritis, kreatif, serta kemampuan bekerjasama. Belajar matematika dapat mengembangkan pola berpikir siswa dalam memecahkan masalah. Abidin (2015) menyatakan masalah seringkali disebut sebagai keadaan yang tidak seimbang antara harapan dengan kenyataan. Kegiatan menyelesaikan masalah yang dihadapi dapat dinamakan pemecahan masalah. Polya (1985) mengungkapkan bahwa pemecahan masalah merupakan usaha menemukan jalan keluar dari sebuah kesulitan untuk mencapai tujuan yang tidak segera dapat dicapai. Ketika siswa dihadapkan suatu masalah matematika, mereka akan berusaha untuk memecahkannya dan menemukan solusi. Kegiatan pemecahan masalah menuntut siswa untuk menggunakan pengalaman dan pengetahuannya agar mencapai tujuan yang diharapkan.

Pemecahan masalah dapat diselesaikan dengan menggunakan berbagai cara. Salah satunya yang diungkapkan Polya (1985) langkah-langkah pemecahan masalah tersebut meliputi (1) memahami masalah (understanding the problem), (2) perencanaan penyelesaian (devising a plan), (3) melaksanakan perencanaan penyelesaian (carrying out the plan), dan (4) memeriksa kembali hasil (looking back). Ditinjau dari pelaksanaannya, belajar pemecahan masalah bukan hal yang mudah, hal tersebut sesuai dengan pernyataan Yeo (dalam Zainuri, 2016) bahwa terdapat beberapa faktor yang menyebabkan kesulitan dalam pemecahan masalah, yaitu (1) siswa kurang memahami masalah yang ada, (2) pengetahuan dalam menentukan strategi pemecahan masalah masih kurang, (3) siswa tidak mampu menerjemahkan masalah ke bentuk matematis, (4) siswa tidak mampu menggunakan konsep matematika yang benar. Sebagai upaya melatih kemampuan siswa dalam pemecahan masalah, khususnya pada siswa kelas V.

Pada proses pemecahan masalah, terdapat perbedaan hasil. Hal tersebut dikarenakan kemampuan pemecahan masalah setiap siswa tidak sama. Menurut Lester (1994) faktor-faktor yang mempengaruhi kemampuan siswa dalam memecahkan masalah, yaitu (1) pengalaman awal siswa, (2) perbedaan kemampuan siswa dalam memahami konsep matematika, (3) motivasi siswa dalam menyelesaikan masalah yang diberikan, (4) bentuk masalah yang diberikan dalam bentuk verbal maupun visual. Perbedaan tersebut mempengaruhi tindakan seseorang jika dihadapkan pada suatu masalah. Ditinjau dari pernyataan Ardana (2008), setiap orang memiliki cara tersendiri dalam bertindak, dilihat melalui aktivitas memahami informasi dan cara berpikir pada masingmasing orang yang berlangsung secara konsisten, hal tersebut dapat diungkapkan melalui gaya kognitif yang dimiliki. 
Gaya kognitif individu dapat dilihat melalui kebiasaan berpendapat, menerima pendapat orang lain, dan pemecahan masalah. Abidin (2015) menyatakan bahwa gaya kognitif merupakan gaya siswa dalam belajar, berkaitan dengan cara menerima dan mengolah informasi, menentukan sikap terhadap informasi, maupun kebiasaan yang dilakukan di lingkungan belajar siswa. Ada jenis-jenis gaya kognitif, yaitu gaya kognitif field independent dan field dependent. Menurut Abidin (2015), orang yang memiliki gaya kognitif field independent lebih analitik sedangkan orang yang memiliki gaya kognitif field dependent cara berpikirnya global. Untuk menguji siswa termasuk ke dalam gaya kognitif field independent atau field dependent dapat dilakukan dengan Group Embedded Figure Test (GEFT) yang dikembangkan oleh Witkin dkk (1977). Tes ini berbentuk gambar sederhana dan kompleks, kemudian subjek mencari gambar sederhana yang terdapat di dalam gambar kompleks dengan cara menebali. Ardana (2008) menyatakan bahwa memanfaatkan gaya kognitif dalam belajar dapat digunakan dalam melihat kemampuan akademis yang dimiliki siswa.

Berdasarkan hal tersebut, peneliti melakukan uji pendahuluan pada tanggal 7 Desember 2018 melalui wawancara kepad guru kelas V SDN Karangbesuki 2, Ibu Baikunniyah, S.Pd. dan pemberian soal kepada 3 siswa kelas V yang dipilih secara acak. Hasil observasi menunjukkan bahwa siswa sudah memperoleh materi pemecahan masalah yang berkaitan dengan geometri pada jenjang kelas sebelumnya, tentang dasar-dasar geometri dan bangun datar. Sebelum proses pemecahan masalah, siswa diberi panduan oleh guru mengenai langkah-langkah penyelesaian masalah. Tetapi pada prosesnya masih ada siswa yang tidak mengikuti langkah-langkah sesuai petunjuk guru. Terbukti dari hasil pemecahan masalah yang dilakukan oleh 3 siswa, terdapat perbedaan kemampuan siswa dalam pemecahan masalah. Siswa pertama melakukan pemecahan masalah sesuai dengan langkah Polya dengan baik dan hasil akhir yang didapat sudah tepat, sedangkan dua siswa lain kurang teliti dalam memecahkan masalah, karena informasi yang dicantumkan belum lengkap serta cara dan hasil akhirnya tidak sesuai dengan yang diharapkan soal.

Penelitian terdahulu yang membahas kemampuan pemecahan masalah pada muatan matematika, yaitu penelitian yang dilakukan Andilala (2018) mengkaji keterampilan pemecahan masalah matematis berdasarkan gaya kognitif dengan subjeknya berasal dari siswa kelas VII, menyebutkan bahwa siswa yang memiliki gaya kognitif field independent mampu menyusun strategi dalam menyelesaikan masalah serta tidak terpengaruh oleh manipulasi dalam konteks masalah. Sedangkan siswa yang memiliki gaya kognitif field dependent kurang lengkap dan kurang terampil dalam menganalisis serta menyelesaikan suatu masalah. Ada penelitian lain yang dilakukan Zainuri (2015) membahas tentang kemampuan siswa dengan gaya kognitif field independent dalam memecahkan masalah matematika berdasarkan langkah-langkah Polya. Subjek 
yang diteliti adalah siswa kelas VII. Penelitian tersebut menyebutkan bahwa siswa dengan gaya kognitif field independent mempu memecahkan masalah matematika sesuai dengan langkahlangkah Polya dengan baik, dengan menemukan keterkaitan antar langkah-langkahnya sehingga dapat ditemukan solusi. Pada penelitian ini akan dideskripsikan kemampuan pemecahan masalah geometri jika dilihat dari gaya kognitif field independent dan field dependent yang dimiliki oleh siswa sekolah dasar, sehingga dirumuskan judul "Analisis Kemampuan Pemecahan Masalah Geometri Berdasarkan Gaya Kognitif pada Siswa Kelas V SDN Karangbesuki 2 Kota Malang”.

\section{METODE}

Penelitian ini bertujuan untuk mendeskripsikan kemampuan pemecahan masalah geometri berdasarkan gaya kognitif field independent dan field dependent pada siswa kelas V SDN Karangbesuki 2 Kota Malang. Berdasarkan tujuan yang diharapkan, penelitian ini menggunakan jenis penelitian kualitatif. Data yang di dapat berupa fakta-fakta yang yang ada di lapangan. Penelitian ini akan mengambil data alamiah tanpa ada manipulasi. Peneliti sebagai pengumpul data, pewawancara, dan analis data. Penelitian dilakukan di SDN Karangbesuki 2 pada tahun ajaran 2018-2019. SDN Karangbesuki 2 terletak di Jalan Candi VA No.389, Karangbesuki, Sukun, Malang. Penelitian dilakukan di kelas V dengan siswa sebanyak 30. Pada penelitian ini diambil 4 subjek penelitian dengan mempertimbangkan gaya kognitif yang dimiliki dan kelancaran komunikasi dengan meminta rekomendasi dari guru kelas.

Sumber data dalam bentuk data primer yang diambil dari (1) hasil Group Embedded Figure Test (GEFT), (2) hasil tes pemecahan masalah geometri, dan (3) hasil wawancara siswa. Analisis data dalam penelitian kualitatif lebih terfokus ketika proses di lapangan bersamaan dengan pengumpulan data. Proses analisis data yang digunakan dalam penelitian ini sesuai dengan model Miles dan Heruman (dalam Sugiyono, 2017), aktivitas analisis data meliputi (1) reduksi data, (2) penyajian data, dan (3) penarikan kesimpulan dan verifikasi. Keabsahan data digunakan agar data yang diperoleh dapat dipercaya dan dapat dipertimbangkan secara ilmiah. Dalam pengecekan keabsahan, peneliti menggunakan metode triangulasi teknik untuk membandingkan data dari hasil tes siswa, data hasil wawancara, dan hasil dokumentasi.

\section{HASIL DAN PEMBAHASAN}

Subjek penelitian ditentukan setelah melakukan tes GEFT, pada hari Rabu, 20 Maret 2019. Berdasarkan hasil GEFT didapatkan siswa yang tergolong memiliki gaya kognitif field independent sebanyak 13 siswa, siswa yang memiliki gaya kognitif field intermediate sebanyak 14 siswa, dan siswa yang memiliki gaya kognitif field dependent sebanyak 3 siswa. Setelah siswa dikelompokkan sesuai dengan gaya kognitif, selanjutnya dihari kedua, 21 Maret 2019 dilakukan 
tes pemecahan masalah kepada seluruh siswa kelas V (Gambar 1). Tes pemecahan masalah terdapat 3 soal yang akan dikerjakan sesuai dengan langkah-langkah pemecahan masalah Polya, yaitu memahami masalah, merencanakan penyelesaian masalah, melaksanakan perencanaan penyelesaian masalah, dan memeriksa kembali. Dari hasil tes GEFT dan tes pemecahan masalah dipilih masing-masing 2 siswa yang memiliki gaya kognitif field independent dan field dependent dengan mempertimbangkan hasil tes dan kelancaran berkomunikasi. Selanjutnya pada hari ketiga, 22 Maret 2019 dilakukan wawancara dengan siswa yang memiliki gaya kognitif field independent, yaitu AR dan SH, serta siswa dengan gaya kognitif field dependent, yaitu GS dan BR. Wawancara yang dilakukan berupa wawancara tidak terstruktur dengan pedoman wawancara yang pertanyaannya akan berkembang sesuai dengan kondisi di lapangan. Pertanyaan berkaitan dengan proses siswa dalam melakukan pemecahan masalah.

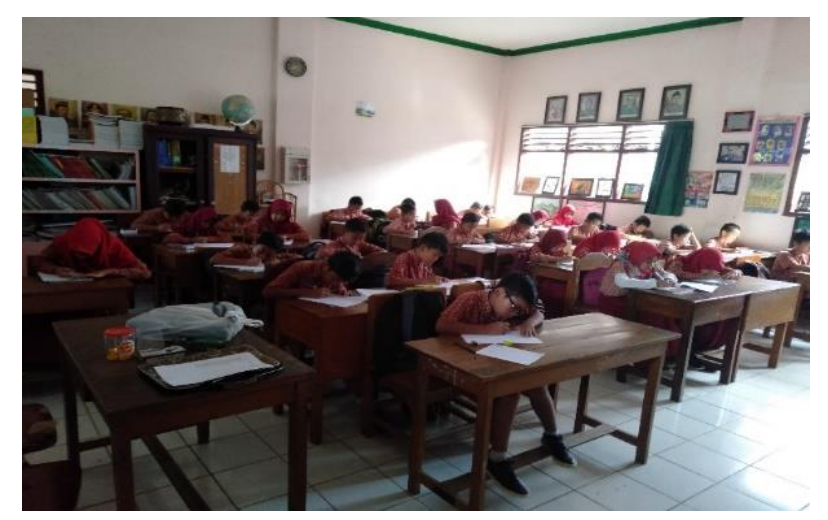

Gambar 1. Siswa Menyelesaikan Tes Pemecahan Masalah

Berdasarkan data yang didapat dalam penelitian, terdapat perbedaan hasil dari siswa dengan gaya kognitif field independent dan field dependent. Berikut hasil penelitian yang dilakukan pada subjek dengan gaya kognitif field independent. Pada lagkah memahami masalah, AR dan SH telah menuliskan informasi yang ada di masalah pertama, kedua dan ketiga. Informasi dijabarkan dengan menuliskan hal-hal yang diketahui dan ditanyakan dalam masalah. AR dan SH menuliskan dalam bentuk uraian secara singkat dan jelas. AR telah mencantumkan semua informasi secara lengkap pada masalah kedua dan ketiga, tetapi pada masalah pertama terdapat informasi yang kurang tepat, karena AR menuliskan konteks yang ditanyakan kurang sesuai dengan masalah. Pada sesi wawancara AR menyadari kesalahan yang dilakukannya tersebut. Sedangkan SH sudah menulis aspek yang diketahui dan ditanyakan dengan tepat dan lengkap pada semua masalah, tetapi dalam penulisan yang ditanyakan tidak terdapat tanda baca yang seharusnya dicantumkan SH, yaitu tanda tanya, karena SH menulis pertanyaan yang wajib diikutkan dalam penulisan kata tanya.

Pada langkah merencanakan penyelesaian masalah, AR dan SH telah menuliskan rencana strategi yang akan digunakan untuk menyelesaikan masalah dengan mencantumkan cara-cara yang 
digunakan. Pada langkah ini AR dan SH mampu menentukan hubungan antara aspek yang diketahui dan ditanyakan sehingga strategi yang ditulisnya relevan untuk menyelesaikan permasalah. AR dan SH juga mampu memberi penjelasan terkait caranya tersebut. AR menuliskan strategi pada masalah kedua dan ketiga dengan tepat, tetapi pada masalah pertama strategi yang digunakan AR tidak relevan dengan yang diinginkan soal. Penyebab dari ketidaksesuaian tersebut karena pada langkah sebelumnya AR kurang tepat dalam menulis yang ditanyakan sehingga berdampak pada jawaban langkah selanjutnya. Sedangkan SH mampu menuliskan strategi yang direncanakan pada masalah pertama dan ketiga. Pada masalah kedua, strategi yang direncanakan SH belum relevan dengan yang ditanyakan. Saat wawancara, SH menyadari hal tersebut tetapi ketika diminta mencari strategi lain, strategi yang diajukan tepat dan dapat digunakan untuk mencari jawabannya.

Pada langkah melaksanakan perencanaan penyelesaian, AR dan SH telah melaksanakan strategi yang dibuat sebelumnya. Pada masalah pertama, SH mencari banyaknya pengisian setengah bagian bak dengan kaleng yang berisi air, SH mampu menyelesaikannya dan hasil akhirnya tepat seperti yang ditanyakan, sedangkan penyelesaian yang dibuat AR kurang tepat, karena cara yang digunakan tidak lengkap dan tidak dapat menemukan hasil akhir yang relevan dengan soal. Pada sesi wawancara, AR menyadari kesalahan tersebut dan mencoba mengajukan cara lagi. Cara yang diajukan dapat digunakan untuk menemukan hasil akhir yang tepat. Pada masalah kedua, AR dapat melaksanakan rencana yang dibuatnya untuk mencari volume masingmasing kubus kecil, hasil akhir yang ditemukan AR sudah tepat dan relevan dengan yang ditanyakan, sedangkan SH yang dari awal mengalami kesulitan menemukan strategi yang cocok untuk memecahkan masalah kedua, hasil akhirnya kurang tepat, karena tidak relevan dengan yang ditanyakan. Tetapi pada sesi wawancara, SH mencoba untuk mencari penyelesaian lain dan penyelesaian yang diajukan tepat untuk menjawab permasalah kedua. Pada masalah ketiga, AR dan SH dapat menemukan lebar dari balok dengan strategi dan hasil akhir yang tepat, relevan dengan yang ditanyakan. Pada langkah memeriksa kembali, AR dan SH memeriksa setiap langkah dan hasil jawaban mereka. AR dan SH juga membuat kesimpulan dari setiap permasalah. Kesimpulan dibuat dengan menggunakan bahasa mereka sendiri.

Berikut hasil penelitian yang dilakukan pada subjek dengan gaya kognitif field dependent. Pada langkah memahami masalah, GS dan BR telah menulis informasi yang berkaitan dengan yang diketahui dan ditanyakan dalam soal. GS dan BR menulisnya dalam bentuk uraian. GS telah menuliskan yang diketahui dan ditanyakan secara lengkap dan sesuai pada masalah pertama saja. Pada masalah kedua dan ketiga, GS menulis yang ditanyakan tidak lengkap karena GS menganggap bahwa yang ditulis lengkap hanya masalah pertama, sehingga pada aspek yang diketahui informasi yang ditulis kurang spesifik. Tetapi pada aspek yang ditanyakan, GS telah 
menulis sesuai dengan informasi pada soal, walaupun GS kurang memberi tanda tanya pada setiap kalimat tanya yang dibuatnya. Sedangkan BR menulis aspek yang ditanyakan kurang lengkap dan terdapat kalimat yang kurang spesifik. Pada aspek yang ditanyakan, BR sudah menuliskan sesuai dengan yang diinginkan soal pada masalah kedua dan ketiga saja, pada masalah kedua informasi yang ditutulis BR kurang spesifik dan tidak sesuai dengan isi soal.

Pada langkah merencanakan penyelesaian masalah, GS dan BR telah menyusun rencana yang dibuat untuk memecahkan masalah. Tetapi rencana yang ditulis kurang relevan dan tidak sesuai dengan yang ditanyakan pada setiap masalah, hal tersebut akan mempengaruhi GS dan BR dalam melaksanakan langkah pemecahan masalah selanjutnya. Pada sesi wawancara GS dan BR mengaku bingung dalam menyusun rencana dan tidak bisa menentukan rumus yang digunakan. GS dan BR menjawab sesuai yang mereka ketahui saja. Pada langkah melaksanakan perencanaan penyelesaian, GS dan BR terpengaruh oleh langkah merencanakan penyelesaian. GS dan BR belum bisa menemukan jawaban akhir yang diinginkan oleh soal. GS dan BR tidak dapat menemukan banyaknya pengisian. Ada juga penulisan bilangan dan pelaksanaan operasi hitung yang kurang tepat. Pada langkah memeriksa kembali, GS dan BR tidak melakukan pemeriksaan ulang atas jawaban yang ditulisnya pada setiap langkah, GS dan BR membuat kesimpulan dari hasil akhirnya, dikarenakan hasil akhirnya kurang tepat jadi kesimpulan yang dibuatnya kurang repat juga. Gambar 2 berikut menunjukkan proses wawancara terhadap subjek penelitian.
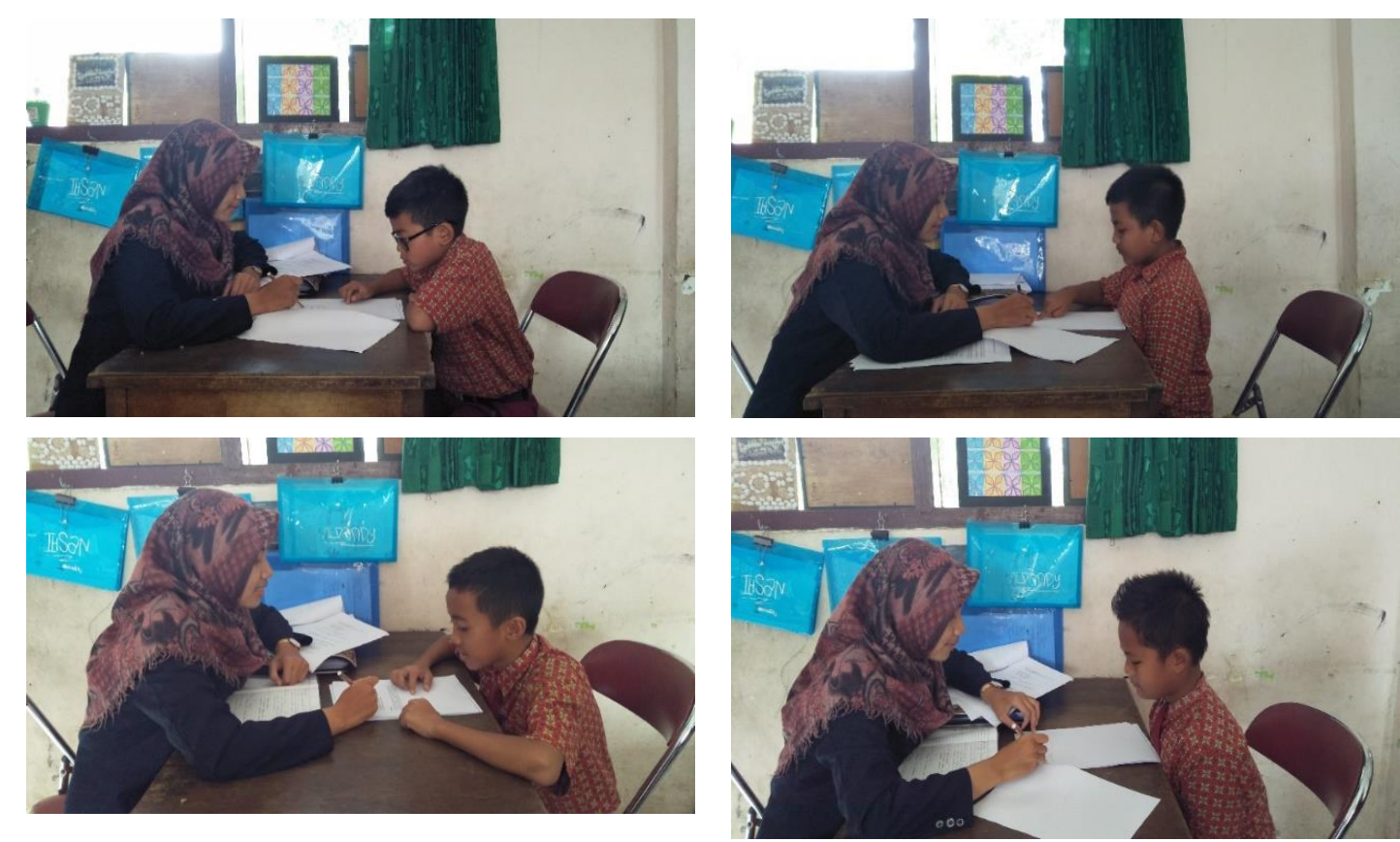

Gambar 2. Wawancara dengan Subjek Penelitian 
Penelitian ini menjabarkan dan mendeskripsikan kemampuan pemecahan masalah geometri berdasarkan gaya kognitif field independent dan field dependent pada siswa kelas V SDN Karangbesuki 2 Kota Malang dengan menggunakan langkah-langkah pemecahan masalah Polya, yaitu (1) memahami masalah, (2) perencanaan penyelesaian, (3) melaksanakan perencanaan penyelesaian, dan (4) memeriksa kembali hasil penyelesaian. Pada langkah memahami masalah, subjek AR dan SH mampu memahami masalah yang diberikan. Hal tersebut terlihat dari AR dan SH mampu menjelaskan informasi dan yang ditanyakan dalam masalah. Mereka menyusunnya dalam bentuk uraian dengan kalimat yang jelas dan rinci. Subjek dengan gaya kognitif field independent menunjukkan bahwa mereka dengan mudah memahami masalah. Sejalan dengan pendapat O'Brien (dalam Puspananda, 2017) bahwa siswa dengan gaya kognitif field independent mampu menerima dan memproses informasi yang diberikan secara teliti karena memiliki kemampuan analisis tinggi. Sedangkan pada siswa yang memiliki gaya kognitif field dependent, yaitu GS dan BR dapat menulis informasi yang ada di dalam masalah, berkaitan dengan yang diketahui dan ditanyakan. GS dan BR menulis dalam bentuk uraian. Tetapi GS dan BR mengalami kesulitan memahami masalah dan informasi yang ditulis kurang lengkap. Sejalan dengan pendapat Khomariyah (2015) bahwa siswa dengan gaya kognitif field dependent cenderung sulit menemukan hal-hal sederhana dari konteks aslinya. Serta pendapat Abidin (2015) bahwa siswa dengan gaya kogntif field dependnet mudah terskecoh oleh konteks yang diberikan dan kurang terstruktur dalam menerima informasi..

Pada langkah merencanakan penyelesaian masalah, siswa dengan gaya kognitif field independent dapat merencanakan setiap strategi yang akan digunakan dalam pemecahan masalah. AR dan SH mampu menemukan hubungan antara yang diketahui dan yang ditanyakan, sehingga dapat digunakan acuan untuk menyusun strategi. Hal tersebut sesuai dengan yang disampaikan Khomariyah (2015) bahwa siswa dengan gaya kognitif field independent tidak terpengaruh oleh manipulasi unsur-unsur konteks dan dapat menyusun rencana sesuai dengan informasi yang diketahuinya. Selain itu Abidin (2015) berpendapat bahwa siswa dengan gaya kognitif field independent lebih analitik dan tidak terpengaruh oleh perubahan konteks. Aspek tersebut menyebabkan AR dan SH mampu menyusun perencanaan yang relevan dengan menggunakan informasi-informasi yang terdapat di dalam soal. Sedangkan pada siswa yang memiliki gaya kognitif field dependent kesulitan dalam menyusun perencanaan penyelesaian masalah. GS dan BR kurang mampu untuk merencanakan strategi yang tepat untuk memecahkan masalah agar relevan dengan yang ditanyakan, karena pada langkah sebelumnya GS dan BR mengalami kendala, hal tersebut mempengaruhi mereka dalam merencanakan penyelesaian masalah.Seperti pendapat yang dikemukakan Abidin (2015) bahwa siswa dengan gaya kognitif field dependent cara 
berpikirnya secara global, sehingga siswa tersebut tidak dapat menguraikan dan mengaitkan informasi-informasi penting yang ada di dalam masalah tersebut.

Pada langkah melaksanakan perencanaan penyelesaian masalah oleh siswa dengan gaya field independent, AR dan SH dapat melaksanakan strategi yang telah dibuatnya. Subjek dengan gaya field independent dapat merealisasikan langkah-langkah yang dibuatnya untuk memecahkan permasalahan dengan cukup tepat. AR dan SH dapat menemukan hasil akhir secara tepat dan relevan dengan yang ditanyakan dalam soal. Sejalan dengan pendapat O'Brien (dalam Puspananda, 2017) bahwa siswa dengan gaya kognitif field independent memiliki kemampuan analisis tinggi dalam menerima dan memproses informasi, sehingga pada proses pemecahan masalah siswa dengan gaya kognitif field independent dapat menghubungan informasi untuk merencanakan strategi penyelesaian dan menemukan hasil akhir yang tepat. Sedangkan pada siswa dengan gaya kognitif field dependent mengalami kesulitan dalam melaksanakan perencanaan penyelesaian dan menentukan rumus, serta ketidaktelitian dalam menulis bilangan sehingga menghambat proses pemecahan masalah. Seperti yang diungkapkan Charles dan Lester dalam (Roebyanto \& Harmini: 2017) bahwa faktor pengalaman yang berkaitan dengan pengetahuan mengenai konteks dan faktor kognitif berkaitan dengan kemampuan membaca soal, menganalisis sangat berperan penting dalam pemecahan masalah. Sejalan dengan pendapat Witkin (1977) bahwa siswa dengan gaya kognitif field dependent kesulitan dalam mempelajari materi yang bersifat terstruktur. Hal tersebut menyebabkan GS dan BR kesulitan dalam memecahkan masalah yang berkaitan dengan muatan matematika.

Pada langkah memeriksa kembali hasil, siswa dengan gaya kognitif field independent mampu membuat kesimpulan berkaitan dengan jawaban yang telah ditemukannya. AR dan SH melakukan pengecekkan ulang untuk menemukan kebenaran dari jawabannya dan dapat menemukan hubungan antara pertanyaan, strategi, dan hasil akhirnya. Sependapat dengan hasil penelitian Zainuri (2015) bahwa siswa dengan gaya kognitif field independent melakukan pemeriksaan kembali atas proses menemukan jawaban dan hasil akhir dari jawaban yang telah diperolehnya. Sedangkan pada siswa dengan gaya kognitif field dependet kurang mampu dalam memeriksa jawaban yang ditemukannya, untuk mempertimbangkan hubungan antar hasil akhir dengan yang ditanyakan dalam soal. GS dan BR dalam menyimpulkan permasalah juga belum rinci dan hasil akhir belum tepat. Hal ini sejalan dengan pendapat Khomariyah (2015) bahwa siswa dengan gaya kognitif field dependent sulit menemukan bagian sederhana dari konteks dan mudah terpengaruh jika ada manipulasi, sehingga dari awal menerima informasi yang ada di dalam soal, subjek GS dan BR terkecoh terhadap kalimat pada soal, yang menyebabkan langkah-langkah pemecahan yang dilakukan kurang tepat. 


\section{SIMPULAN DAN SARAN}

\section{Simpulan}

Berdasarkan hasil penelitian yang telah dilakukan di SDN Karangbesuki 2 ditemukan bahwa siswa yang memiliki gaya kognitif field independent dalam penelitian ini mampu memecahkan masalah geometri sesuai dengan langkah-langkah polya dengan baik. Pada langkah memahami masalah subjek mampu memahami informasi sehingga dapat menentukan yang diketahui dan ditanyakan di dalam soal. Pada langkah menyusun merencanakan penyelesaian subjek mampu menganalisis hubungan yang diketahui dan ditanyakan sehingga dapat menyusun strategi yang cocok untuk memecahkan masalah. Pada langkah melaksanakan perencanaan penyelesaian subjek mampu mengaplikasikan strategi yang sudah direncanakan, sehingga dapat menemukan hasil akhir yang tepat dan sesuai yang diinginkan soal. Pada langkah yang terakhir, memeriksa kembali hasil. Subjek dapat melakukan penyimpulan dari hasil yang diperolehnya dan memastikan bahwa jawaban yang didapat sudah tepat seperti yang diharapkan soal.

Siswa yang memiliki gaya kognitif field dependent dalam penelitian ini kurang mampu memecahkan masalah geometri sesuai langkah-langkah polya. Pada langkah memahami masalah, subjek kurang lengkap dalam menuliskan informasi, sehingga aspek-aspek penting tidak ditulis seluruhnya pada bagian yang diketahui dan ditanyakan. Pada langkah menyusun perencanaan penyelesaian, subjek kurang mampu menyusun strategi untuk memecahkan masalah yang tepat. Subjek tidak mampu membuat rencana penyelesaian relevan dengan yang ditanyakan. Pada langkah melaksanakan perencanaan penyelesaian, subjek melaksanakan strateginya, tetapi karena strategi yang dibuatnya tidak sesuai dengan yang ditanyakan jadi hasil akhir dari jawabannya kurang tepat. Selain itu, subjek juga tidak teliti dalam menulis bilangan dan melakukan operasi hitung. Pada langkah memeriksa kembali, subjek kurang mampu dalam membuat kesimpulan dari jawabannya, selain itu subjek tidak melakukan pemeriksaan kembali hasilnya.

\section{Saran}

Berdasarkan hasil penelitian yang didapat, hal-hal yang dapat disarankan, yaitu (1) siswa yang memiliki gaya kognitif field independent diberikan latihan pemecahan masalah agar kemampuannya lebih terasah lagi dan matang, (2) siswa yang memiliki gaya kognitif field dependent memerlukan bantuan dan motivasi dari guru agar mampu melakukan pemecahan masalah pada muatan matematika materi geometri, (3) penelitian ini hanya dilakukan untuk mengetahui sejauh mana kemampuan yang dimiliki siswa dengan gaya kognitif field independent dan field dependent dalam memecahkan masalah, sehingga diperlukan penelitian lebih lanjut yang berkaitan dengan gaya kognitif lainnya dan materi yang berbeda, sehingga dapat menjadi referensi guru untuk menentukan model dan strategi pembelajaran yang tepat sesuai gaya kognitif yang dimiliki siswa. 


\section{DAFTAR RUJUKAN}

Abidin, Z. (2015). Intuisi dalam Pembelajaran Matematika: Konstruksi Pemecahan Masalah Devergen dengan Gaya Kognitif Field Independent dan Field Dependent. Jakarta: Lentera Ilmu Cendikia.

Andilala, D. L. (2018). Analisis Keterampilan Pemecahan Masalah Matematis Siswa Berdasarkan Gaya Kognitif di Kelas VII MTS Negeri Probolinggo. Malang: Universitas Negeri Malang,

Ardana, I. M. (2008). Peningkatan Kualitas Belajar Siswa Melalui Pengembangan Pembelajaran Matematika Berorientasi Gaya Kognitif dan Berwawasan Konstruktivis. Bali: Undiksha.

Daryanto dan Raharjo, M. (2012). Model Pembelajaran Inovatif. Yogyakarta: Gava Media.

Khomariyah, N. (2015). Proses Koneksi Matematika dalam Memecahkan Masalah Berdasarkan Gaya Kognitif Field Dependent dan Field Independent Siswa SMA Negeri 1 Beruntung Baru. Malang: Universitas Negeri Malang

Lester, F. K. (1994). Musing about Mathematical Problem Solving Research. Journal for Research in Mathematics Education. (online) (https://www.researchgate.net/publication/269478954_Musings_about_Mathematical_ProblemSolving_Research 1970-1994), diakses 17 Januari 2019

Roebyanto, G. dan Harmini, S. (2017). Pemecahan Masalah Matematika untuk PGSD. Bandung: PT Remaja Rosdakarya.

Polya, G. (1985). How To Solve It 2nd ed. New Jersey: Princeton University Press.

Puspananda, D.R dan Suriyah, P. (2017). Analisis Faktor pada Group Embbeded Figures Test untuk Mengukur Gaya Kognitif. IKIP PGRI Bojonegoro.

(online),(http://seminar.uny.ac.id/semnasmatematika/sites/seminar.uny.ac.id.semnasmatematika/files/fu 11/M-34.pdf), diakses 2 Januari 2019.

Witkin, H. A., \& Goodenough, D. R. (1977). Field dependence and interpersonal behavior. Psychological bulletin, 84(4), 661.

Zainuri, T. (2016). Analisis Kemampuan Siswa dengan Gaya Kognitif Field Independent dalam Memecahkan Masalah Matematika Berdasarkan Langkah-langkah Polya. Disertasi tidak diterbitkan. Malang: Pascasarjana Universitas Negeri Malang. 